\title{
Evaluasi Program Pemberdayaan Usaha Mikro Kecil dan Menengah (UMKM) LAZISMU Magetan dengan Pendekatan Diagram Kartesius
}

\section{Evaluation of the LAZISMU Magetan Empowerment Program for Micro, Small and Medium Enterprises (MSMEs) with a Cartesian Diagram Approach}

\author{
Azhar Alam ${ }^{1}$ Harun$^{2}$, Nisrina Mar-atus Sholihah ${ }^{3}$, Aditya Nurrahman ${ }^{4}$ \\ ${ }^{1}$ Universitas Muhammadiyah Surakarta, Fakultas Agama Islam, Jl. A. Yani, Surakarta 57162, \\ Indonesia, aal23@ums.ac.id \\ ${ }^{2}$ Universitas Muhammadiyah Surakarta, Fakultas Agama Islam, J1. A. Yani, Surakarta 57162, \\ Indonesia, har179@ums.ac.id \\ ${ }^{3}$ Universitas Muhammadiyah Surakarta, Fakultas Agama Islam, Jl. A. Yani, Surakarta 57162, \\ Indonesia, nisrinms97@gmail.com \\ ${ }^{4}$ Universitas Muhammadiyah Surakarta, Fakultas Agama Islam, Jl. A. Yani, Surakarta 57162, \\ Indonesia, adityanurrahman040@gmail.com
}

\begin{abstract}
This study aimed to determine the effect of zakat empowerment with MSMEs on the economic people empowerment according to the mustahik perceptions. This research used descriptive analysis with Cartesian coordinate approach. The results showed that the quality of LAZISMU in the MSMES empowerment program in each dimension of tangible, reliability, responsiveness, assurance, and empathy was almost entirely good quality. The tangible dimension can be shown through the ease of procedures for submitting assistance and the period of its realization. The suitability between everything described by the officer with the reality on the reliable dimension is the main priority factor. The politeness, friendliness and communication skill of officers in the empathy dimension are factors that must be maintained. While transparency in providing information on survey results on the assurance dimension is a low priority factor. The monitoring on the impact of empowerment on the responsiveness dimension and the strategic location of the LAZISMU office on the tangible dimension was considered excessive. There is an effect of zakat empowerment with MSMEs on increasing the people's economic income in terms of service quality according to the perceptions of mustahik. This research suggests LAZISMU Magetan for accelerates the realization of assistance proposals and the ease in applying for assistance.
\end{abstract}

Keywords: Cartesius diagram, economy, empowerment, LAZISMU, mustahik.

\begin{abstract}
Abstrak. Tujuan penelitian ini adalah untuk mengetahui pengaruh pemberdayaan zakat dengan UMKM pemberdayaan ekonomi umat menurut persepsi mustahik. Penelitian ini menggunakan analisis deskriptif dengan pendekatan diagram Kartesius. Hasil penelitian menunjukkan kualitas LAZISMU dalam program pemberdayaan UMKM pada masing-masing dimensi tangible, reliability, responsiveness, assurance, dan emphaty hampir seluruhnya cukup berkualitas. Dimensi tangible dapat ditunjukkan melalui kemudahan tata cara dalam pengajuan bantuan dan rentang waktu realisasi dengan pengajuan bantuan. Kesesuaian antara segala hal yang dijelaskan petugas dengan kenyataan pada dimensi reliable menjadi faktor prioritas utama. Sopan santun, keramahan petugas dan kemampuan komunikasi petugas pada dimensi emphaty menjadi faktor yang harus dipertahankan. Sedangkan transparansi dalam memberikan informasi hasil survei pada dimensi assurance menjadi faktor prioritas rendah. Pemantauan terhadap dampak pemberdayaan pada dimensi responsiveness dan letak strategis kantor LAZISMU pada dimensi tangible dinilai berlebihan. Ada pengaruh pemberdayaan zakat dengan UMKM terhadap peningkatan pendapatan ekonomi umat ditinjau dari kualitas layanan menurut persepsi mustahik. Penelitian ini menyarankan LAZISMU Magetan untuk mempercepat darealisasi pengajuan bantuan dan kemudahan dalam pengajuan bantuan.
\end{abstract}

Kata kunci: Ekonomi, diagram Kartesius, LAZISMU, mustahik, pemberdayaan. 


\section{PENDAHULUAN}

UMKM (Usaha Mikro Kecil Dan Menengah) adalah salah satu kunci dari suksesnya pembangunan nasional. Hal ini terbukti karena UMKM bisa tumbuh dan berkembang saat krisis melanda Indonesia. Selain itu, UMKM mampu memberikan peluang untuk tetap berkembang dan tidak kalah bersaing dengan perusahaan yang cenderung menggunakan modal lebih besar (Izdihar dan Widiastuti, 2019).

Dari tahun ke tahun, jumlah penduduk miskin dan pengangguran semakin meningkat disebabkan penduduk tidak memiliki pekerjaan. Penduduk yang menganggur terdapat di daerah pedesaan maupun perkotaan. Adanya pengangguran di pedesaan disebabkan tingkat pendidikan masyarakat yang rendah dan kurangnya keterampilan atau keahlian khusus yang dimiliki. Pengangguran di daerah perkotaan disebabkan sulitnya para pencari kerja mendapatkan pekerjaan, baik di kantor pemerintah ataupun di perusahaan akibat persyaratan yang tidak sesuai dengan kualifikasi diri pencari kerja. Selain itu, adanya krisis ekonomi membuat banyaknya Pemutusan Hubungan Kerja (PHK) (Rohmah, 2014).

Lembaga Amil Zakat Infaq Shadaqah Muhammadiyah (LAZISMU) sebagai salah satu lembaga tingkat nasional, senantiasa peduli dan tanggap terhadap dinamika dan perkembangan kehidupan masyarakat di tanah air dan mancanegara. LAZISMU berfokus pada pemberdayaan masyarakat melalui pemanfaatan secara produktif dari dana infak, zakat, wakaf, serta dana lainnya dari para dermawan baik perseorangan, lembaga, perusahaan, dan institusi lainnya. LAZISMU didirikan pada 4 Juli 2002 oleh Pimpinan Pusat (PP) Muhammadiyah. Dikukuhkan sebagai Lembaga Amil Zakat Nasional oleh Menteri Agama Republik Indonesia melalui SK No. 457/21 November 2002. Selanjutnya melalui SK Kemenag RI No. 730 Tahun 2016, LAZISMU dikukuhkan kembali sebagai LAZNAS guna mengikuti perundang-undangan RI.

LAZISMU memiliki program yang disusun menjadi lima pilar utama, yakni pendidikan, dakwah, sosial kemanusiaan, kesehatan, dan ekonomi. Bekerja dengan memegang prinsip dapat dipercaya, profesional serta transparan, LAZISMU berusaha untuk mengembangkan diri menjadi Lembaga Amil Zakat yang terpercaya. Program-program LAZISMU disusun dan dikembangkan menjadi model pemberdayaan yang berdampak pada peningkatan kualitas hidup, terjadinya perubahan sosial dan meningkatnya taraf kesejahteraan masyarakat (LAZISMU Jateng, 2020).

LAZISMU Magetan menaungi 80 Usaha Mikro Kecil dan Menengah (UMKM), salah satunya adalah usaha dagang dan jasa. Pemberdayaan LAZISMU mengacu pada model PRA (Participatory Rural and Appraisal) yaitu pemberdayaan masyarakat yang lebih banyak melibatkan pihak dalam dan pihak luar. Adapun pihak dalam yaitu muzaki dan pengurus, sedangkan pihak luar sebagai fasilitator. Metode PRA merupakan metode penilaian keadaan secara partisipatif yang dilakukan pada tahapan awal perencanaan kegiatan. Dalam PRA terdapat lima kegiatan pokok yaitu: Pengenalan kebutuhan, perencanaan kegiatan, pelaksanaan/pengorganisasian kegiatan, pemantauan kegiatan, dan evaluasi kegiatan.

Pengenalan kebutuhan ditinjau dari pengajuan yang dilakukan oleh mustahik. Perencanaan dan pelaksanaan ditentukan oleh pengurus. Sedangkan pemantauan dan evaluasi dilaksanakan oleh pengurus dan muzaki. Hasil survei awal menurut mustahik setelah menerima bantuan terdapat peningkatan dari pendapatan ekonomi dan fasilitas.

Penelitian ini bertujuan untuk memberikan evaluasi terhadap progam pemberdayaan UMKM oleh LAZISMU Magetan dengan suatu metode penilaian layanan jasa diagram Kartesius. Penelitian ini bertujuan untuk menambah kekayaan literatur dalam evaluasi progam lembaga zakat dan mengenalkan metode diagram Kartesius sebagai salah satu metode evaluasi terhadap penyelenggaran progam pemberdayaan zakat. Penelitian berbeda dengan model CIBEST yang digunakan Beik dan Arsyianti (2015) sebagai pengukuran atas kemiskinan dan kesejahteraan dalam perspektif Islam. 
Kondisi di Indonesia, banyak lembaga zakat yang didirikan, tetapi pengelolaannya belum maksimal. Maka dari itu, penting untuk dilakukan penelitian terkait evaluasi program pemberdayaan lembaga zakat, agar kinerja lembaga zakat semakin meningkat. Terlebih lagi masih belum banyak penelitian yang membahas tentang kajian evaluatif dalam meningkatkan progam yang dimiliki lembaga zakat. Adapun tujuan penelitian ini memberikan penilaian evaluasi dengan menggunakan pendekatan diagram Kartesius yang biasa digunakan untuk menilai kinerja dari lembaga penyedia jasa atau layanan.

\section{TINJAUAN PUSTAKA}

\section{Investasi pada Harta Zakat}

Secara bahasa, zakat merupakan kata yang memiliki arti tumbuh dan keberkahan. Pelaksanaan pembayaran zakat juga mensyaratkan ibadah maliyah yang berkaitan erat dengan harta tertentu yang dimiliki oleh seseorang (Sarwat, 2019).

Para pakar fikih kontemporer sebagian berpendapat boleh untuk melakukan investasi pada harta zakat, baik yang jumlahnya sedikit ataupun banyak. Syekh Mustafa Zarqa, Yusuf Qardhawi, Abdul Fattah Abu Ghuddah, serta keputusan Majma' Al-Fikih Al-Islami dalam Sanrego dan Taufik (2016) menyebutkan: "Pada prinsipnya, boleh saja mengembangkan harta zakat sebagai usaha yang kepemilikannya untuk mustahik, atau bisa juga dikelola oleh pihak lembaga amil zakat yang memiliki tugas mengumpulkan sekaligus membagikan zakat. Tentunya dengan syarat harta tersebut adalah sisa dari harta zakat yang telah terlebih dahulu dibagikan untuk mencukupi kebutuhan-kebutuhan pokok para mustahik dan ada jaminan dari pihak pengelola".

Investasi harta zakat adalah suatu bentuk usaha yang bertujuan mengembangkan harta zakat pada jangka waktu tertentu. Di mana dalam mengembangkannya menggunakan berbagai metode investasi yang tentunya diperbolehkan dalam rangka memberikan manfaat bagi yang berhak menerima zakat. Artinya, harta zakat dari beberapa orang dikumpulkan. Kemudian hasil dari keuntungan kegiatan industri dibagikan secara rutin setiap bulan kepada fakir miskin. Dan meski status kepemilikannya milik bersama, si pemilik tidak memiliki hak untuk menjual bagiannya pada usaha tersebut. Harta zakat yang diterima badan amil harus segera dibagikan, tidak boleh ditunda. Apabila si pengelola bukan seorang mustahik dan usahanya rugi atau jika pengelolanya tidak amanah tentulah zakat akan hilang dan bisa menimbulkan kerugian pada fakir miskin.

\section{Pemberdayaan pada Lembaga Zakat}

Pemberdayaan merupakan perolehan akses dan kekuasaan terhadap sumber daya untuk mencari nafkah juga mendorong perubahan sosial. Hal itu memberikan peluang bagi masyarakat di pinggiran dalam memberikan pengaruh lebih besar di arena politik secara lokal maupun nasional. Pemberdayaan hakikatnya merupakan salah satu upaya mewujudkan suasana kemanusiaan yang adil dan beradab juga semakin efektif dan terstruktur; baik dalam kehidupan keluarga, masyarakat umum, negara, daerah, dan internasional. Begitupun di bidang politik, ekonomi, dan lain sebagainya (Sanrego dan Taufik 2016).

Rohmah (2014) mengkaji pemberdayaan Usaha Mikro, Kecil dan Menengah (UMKM) pada lembaga inkubator bisnis BAZNAS menggunakan pendekatan kualitatif deskriptif. Hasil penelitian menunjukkan lembaga inkubator bisnis BAZNAS menggunakan metode ini dengan membidik para pelaku UMKM. Pemberdayaan bertujuan untuk menambah penghasilan, dilakukan dengan cara meningkatkan keterampilan, memberikan modal serta pemberian link pasar kepada pelaku usaha.

Wijayanti (2015) menganalisis implementasi pemberdayaan usaha mikro pada LAZISMU Kabupaten Malang. Tujuan penelitian adalah untuk mengidentifikasi terkait pola pemberdayaan dan manajemen LAZISMU Kabupaten Malang dalam melakukan langkah strategis pengembangan usaha mikro. 
Pendekatan kualitatif digunakan dalam penelitian karena permasalahan kompleks, dinamis dan penuh makna. Hasil penelitian menjelaskan bahwa program LAZISMU berfokus dan berorientasi pada keproduktifan untuk menciptakan masyarakat mandiri, salah satunya bidang pengembangan ekonomi masyarakat.

Ariani dan Anwar (2018) mengkaji program pemberdayaan zakat bagi UMKM pada Rumah Zakat Kota Surabaya. Pendekatan yang digunakan adalah deskriptif kualitatif. Hasil dari penelitian menjelaskan bahwa model pemberdayaan di Rumah Zakat Kota Surabaya dilakukan dengan melakukan pendataan dari penerima zakat, kemudian dilakukan survei dan wawancara atas kelayakan usaha, dilanjutkan dengan pendampingan penerima zakat yakni konsultasi dan evaluasi usaha dengan melibatkan mitra dalam hal ini pihak ketiga yaitu PIC atau relawan. Pencapaian program pemberdayaan UMKM pada rumah zakat secara keseluruhan telah optimal.

Kholidah dan Salma (2020) meneliti filantropi kreatif dalam pemberdayaan ekonomi umat berbasis zakat produktif pada program 1000 UMKM LAZISMU Kabupaten Pekalongan. Jenis pendekatan yang digunakan adalah kualitatif deskriptif. Hasil penelitian menjelaskan bahwa pemberdayaan UMKM dengan program 1000 UMKM dijalankan dengan baik. Meski demikian, masih kurang berdampak kepada masyarakat. Penerima manfaat dana bergulir masih terlalu sedikit. Hal ini dikarenakan kurangnya sumber daya manusia untuk program tersebut.

LAZISMU Kabupaten Pekalongan selaku fasilitator berperan aktif dalam membantu para mustahik yang mengalami kesulitan untuk melakukan pengembangan usahanya. Ada dampak positif dari program 1000 UMKM berbasis zakat produktif ini, salah satunya mampu meningkatkan penghasilan usaha penerima hibah. Mereka dapat memperluas jaringan usaha sehingga laba pun meningkat. Ada juga peningkatan pengetahuan, keterampilan serta peningkatan kemampuan pengelolaan usaha. Sehingga pemberdayaan ini dapat berdampak pada keseluruhan aspek kehidupan masyarakat misalnya agama, sosial, dan ekonomi.

Lubis dan Andayani (2017) meneliti pengaruh kualitas pelayanan (service quality) terhadap kepuasan pelanggan PT. Sucofindo Batam. Dalam penelitian tersebut digunakan metode analisis deskriptif dan analisis regresi berganda menggunakan program SPSS 20. Hasil penelitian menunjukkan bahwa semua dimensi secara parsial berpengaruh positif dan signifikan terhadap kepuasan pelanggan.

Setiawan et al. (2019) menelaah tentang pengaruh kualitas pelayanan terhadap kepuasan pelanggan. Jenis penelitian yang digunakan adalah deskriptif kuantiatif. Tujuan penelitian untuk menganalisis pengaruh kualitas pelayanan terhadap kepuasan konsumen baik secara parsial atau simultan. Hasil penelitian menunjukkan bahwa pengujian seluruh dimensi secara simultan berpengaruh positif dan signifikan terhadap kepuasan konsumen.

Hakim et al., (2020) mengkaji zakat dan pemberdayaan ekonomi mustahik pada LAZISMU Kabupaten Malang. Metode yang digunakan adalah kualitatif deskriptif. Hasil penelitian menunjukkan pendayagunaan zakat di LAZISMU Kabupaten Malang mampu untuk meningkatkan pemberdayaan ekonomi mustahik.

Rizal et al. (2020) mengkaji tentang pemasaran produk usaha mikro, kecil dan menengah dalam kegiatan wisata di Desa Cipacing, Kabupaten Sumedang. Hasil penelitian menunjukkan bahwa metode PRA berguna dalam mengawasi kecenderungan perubahan-perubahan di pedesaan untuk mengurangi ketidakpastian yang terjadi di lapangan dan mengusulkan penyelesaian masalah yang mungkin terjadi. Tujuan dari program tersebut yaitu untuk meningkatkan potensi masyarakat melalui pemasaran berbasis media sosial. 


\section{Dimensi Penilaian Kualitas Pelayanan Lembaga Zakat}

Kepuasan pelanggan ialah tingkat perasaan seseorang setelah membandingkan kinerja (hasil) yang dirasakan dengan harapan. Kualitas memiliki hubungan yang erat dengan kepuasaan pelanggan. Kualitas menghadirkan dorongan kepada pelanggan untuk menjalin kerjasama yang kuat dengan perusahaan (Tjiptono, 2006). Hubungan kepuasan pelanggan layanan sebuah lembaga merupakan hal penting dalam menggambarkan kepercayaan para pengguna jasa dari lembaga tersebut. Sebuah lembaga zakat perlu memperhatikan para stakeholder termasuk setiap dari pengguna layanannya (muzaki dan mustahik). Dimensi kualitas dari jasa sering disebut servqual dimension (service quality dimension). Servqual dimension menurut Lovelock terdiri atas dimensi tangible, reliability, responsiveness, assurance, dan emphaty (Santoso, 2011).

LAZISMU sebagai lembaga pengelola zakat dalam kegiatannya adalah mengumpulkan zakat dari muzaki dan membagikan zakat kepada mustahik. Syariat Islam memberikan syarat standar kepada pengelola/amil zakat antara lain Islam, akil balig, jujur, mempunyai ilmu tentang hukum zakat, dan mempunyai kekuatan fisik dan hukum (Sarwat, 2019). Kualitas layanan LAZISMU kepada mustahik dapat dinilai dengan mengacu pada persyaratan tersebut dan dapat ditinjau dari beberapa dimensi sebagaimana menurut Parasuraman, Zeithmal, dan Berry dalam Santoso (2011), yaitu:

\section{Tangible (Bukti Fisik)}

a) Letak strategis kantor LAZISMU akan mempermudah muzaki untuk menyalurkan zakat, begitu juga mustahik akan dipermudah untuk mengambil zakat.

b) Sarana informasi seperti surat, telepon, email, website akan mempercepat penyampaian informasi kepada muzaki dan mustahik.

c) Pedoman administrasi yang baku untuk mendata siapa saja yang wajib serta berhak atas zakat (Sarwat, 2019).

d) Sarana penyaluran zakat bagi mustahik yang tidak mampu mengambil.

e) Bukti fisik zakat baik dalam bentuk uang ataupun barang.

2. Reliable (Keandalan)

a) Adanya kemudahan bagi mustahik dalam pengajuan bantuan.

b) Zakat dibagikan tepat waktu.

c) Zakat memberikan manfaat untuk meningkatkan kesejahteraan. Sebagaimana pada masa khalifah Umar bin Khatab, Provinsi Yaman mampu mengentaskan kemiskinan. Gubernur Mu'adz bin Jabal membagikan sepertiga dari total hasil zakat ke Madinah karena tidak bisa dibagi lagi di Yaman.

d) Amil zakat berakal sehat, balig dalam arti mampu menanggung beban syariah, dan menguasai ilmu tentang zakat.

3. Responsiveness (Daya Tanggap)

a) Amil zakat menentukan sasaran/mustahik dengan tepat.

b) Respons yang cepat terhadap pengajuan bantuan dari mustahik.

c) Amil zakat mampu memberikan solusi terhadap permasalahan mustahik.

d) Adanya pemantauan terhadap penggunaan zakat oleh mustahik.

4. Assurance (Jaminan)

a) Kejujuran amil zakat dalam memberikan informasi tentang hasil survei dalam menentukan mustahik.

b) Ada informasi yang jelas/transparan dalam pengelolaan zakat.

c) Adanya jaminan keberlangsungan pemberian zakat.

5. Emphaty (Perhatian)

a) Amil zakat berperilaku sopan.

b) Adanya perlakuan yang sama/tidak membeda-bedakan terhadap semua mustahik.

c) LAZISMU menerima masukan/keluhan dari mustahik untuk meningkatkan layanan. 


\section{Persepsi Konsumen}

Persepsi merupakan proses dari seorang individu dalam memilih, mengorganisasi, serta menafsirkan suatu informasi sehingga menciptakan suatu gambaran yang lebih bermakna. Setiap orang memiliki persepsinya masing-masing, walaupun mereka dihadapkan pada situasi dan kondisi yang sama (Kotler, 1997).

Kualitas ada dua yaitu kualitas objektif dan kualitas menurut pelanggan/perceived quality, yang terpenting adalah kualitas di mata konsumen (Simamora, 2020). Tiga perceived quality dijelaskan oleh Simamora (2020) sebagai berikut:

1. Ada tiga aspek utama dari kualitas yang dinilai oleh konsumen pada suatu produk mencakup produk, harga, dan nonproduk.

2. Kualitas akan ada jika produk bisa dipersepsikan dengan baik oleh konsumen. Sebab, produk dinilai memiliki kualitas yang baik atau tidak tergantung bagaimana pelanggan mampu mempersepsikannya. Bahkan sekalipun produk tersebut kurang baik, jika menurut pelanggan baik, maka kualitas produknya pun akan baik.

3. Perceived quality artinya melakukan pengukuran produk dengan pesaing. Setidaknya kualitas produk tidak lebih rendah dari pesaing lainnya.

Berdasarkan penelitian dimensi kualitas dalam Simamora (2020), faktor-faktor yang memengaruhi perceived quality khususnya pada kualitas layanan adalah:

1. Tangible (Aspek Fisik)

2. Reliability (Aspek Keandalan)

3. Assurance (Aspek Kompetensi)

4. Responsiveness (Aspek Tanggung Jawab)

5. Emphaty (Aspek Empati)

\section{METODE}

Pendekatan dalam penelitian ini menggunakan metode penelitian deskriptif, yang bertujuan untuk menggambarkan atau mendeskripsikan suatu keadaan secara objektif dalam rangka memecahkan atau menjawab permasalahan yang sedang dihadapi pada situasi terkini. Gambaran kualitas program pemberdayaan UMKM dalam dimensi tangible, reliability, responsiveness, assurance, dan emphaty akan dijelaskan pada penelitian ini. Pada penelitian ini adalah seluruh mustahik LAZISMU Magetan berjumlah 61 orang dan semuanya dijadikan sampel. Penelitian ini dilaksanakan pada bulan Juni 2019 sampai Agustus 2019. Penelitian ini menggunakan metode diagram Kartesius dengan tujuan analisis terhadap mutu pelayanan LAZISMU Magetan dalam progam pemberdayaan UMKM. Metode diagram Kartesius merupakan metode yang umumnya dipakai untuk mengukur prioritas utama yang dalam konteks zakat salah satunya oleh para mustahik (Kosasih, 2014).

Sumber data yang digunakan berasal dari data primer yakni data yang diperoleh secara langsung dari pihak pertama kepada pengumpul data melalui wawancara. Berdasarkan hasil wawancara dengan mustahik (Bapak Suparno, Bapak Joko, Bapak Kemis dan Ibu Ngatinah) dapat disimpulkan bahwa ada peningkatan pendapatan yang dapat dilihat dari segi kebutuhan sehari-hari dapat tercukupi, penghasilan meningkat dari sebelumnya, dan pelanggan menjadi bertambah.

Data primer lainnya diperoleh hasil kuesioner yang dibagikan ke mustahik. Data dikumpulkan dengan cara membagikan kuesioner kepada sejumlah subjek dalam rangka mendapatkan tanggapan, informasi dan jawaban. Kuesioner adalah salah satu alat pengumpulan data, digunakan pada penelitian yang umumnya menyangkut persoalan serta kepentingan banyak orang. Alat pengumpul data ini cocok digunakan dalam rangka memperoleh data yang cukup luas pada suatu kelompok atau masyarakat dengan populasi yang besar dan tersebar daerahnya (Sugiyono, 2012). 
Pengumpulan data dilakukan dengan membagikan kuesioner pada mustahik. Kuesioner dalam penelitian ini telah dilakukan uji validitas dan reliabilitas dengan hasil semua item valid dan reliabel. Pada penelitian ini kuesioner berbentuk daftar pertanyaan tertutup yang tersedia sebanyak 25 pertanyaan, distribusi dari masing-masing dimensi lima pertanyaan. Pilihan jawaban pada kuesioner tingkat kepentingan yaitu:

1. Jawaban sangat penting memiliki bobot 4 .

2. Jawaban penting memiliki bobot 3 .

3. Jawaban kurang penting memiliki bobot 2 .

4. Jawaban tidak penting memiliki bobot 1 .

Sedangkan pilihan jawaban pada kuesioner tingkat kinerja yaitu:

1. Jawaban sangat baik memiliki bobot 4 .

2. Jawaban baik memiliki bobot 3 .

3. Jawaban kurang baik memiliki bobot 2 .

4. Jawaban tidak baik memiliki bobot 1 .

\section{Metode Analisis Data dan Pengolahan}

\section{Teknik analisis data}

Analisis data untuk masing-masing dimensi kualitas jasa dilakukan dengan menggunakan metode deskriptif berupa distribusi frekuensi dan disajikan dalam diagram Pie. Selanjutnya menentukan prioritas mutu/kualitas dengan diagram Kartesius. Pada diagram Kartesius, sumbu mendatar (X) akan diisi skor tingkat kepuasan (performance), sedangkan sumbu tegak (Y) akan diisi oleh skor tingkat kepentingan (importance). Atribut-atribut mutu yang ada dipetakan sesuai dengan tingkat kepuasan dan kepentingannya $(\mathrm{X}, \mathrm{Y})$. Rumus untuk setiap faktor tersebut, yaitu:

$$
\bar{X}=\frac{\sum_{i=1}^{n} X i}{n} \operatorname{dan} \bar{Y}=\frac{\sum_{i=1}^{n} Y i}{n}
$$

Keterangan: $\bar{X}=$ Skor rata-rata tingkat kinerja/pelaksanaan

$\bar{Y}=$ Skor rata-rata tingkat kepentingan

$\mathrm{n}=$ Jumlah responden

Dalam penjabarannya, diagram Kartesius dibagi menjadi 4 kuadran dan dibatasi dua buah garis saling berpotongan tegak lurus pada nilai rata-rata tingkat kepentingan dan kepuasan seluruh atribut mutu $(\overline{\bar{X}}, \overline{\bar{Y}})$, titik-titik tersebut diperoleh dari rumus:

$$
\overline{\bar{X}}=\frac{\sum_{i=1}^{n} \overline{X l}}{K} \operatorname{dan} \overline{\bar{Y}}=\frac{\sum_{i=1}^{n} \bar{Y} \bar{Y}}{K}
$$

Keterangan:

$\mathrm{K}=$ Banyaknya atribut fakta yang mempengaruhi kepuasan pelanggan. 


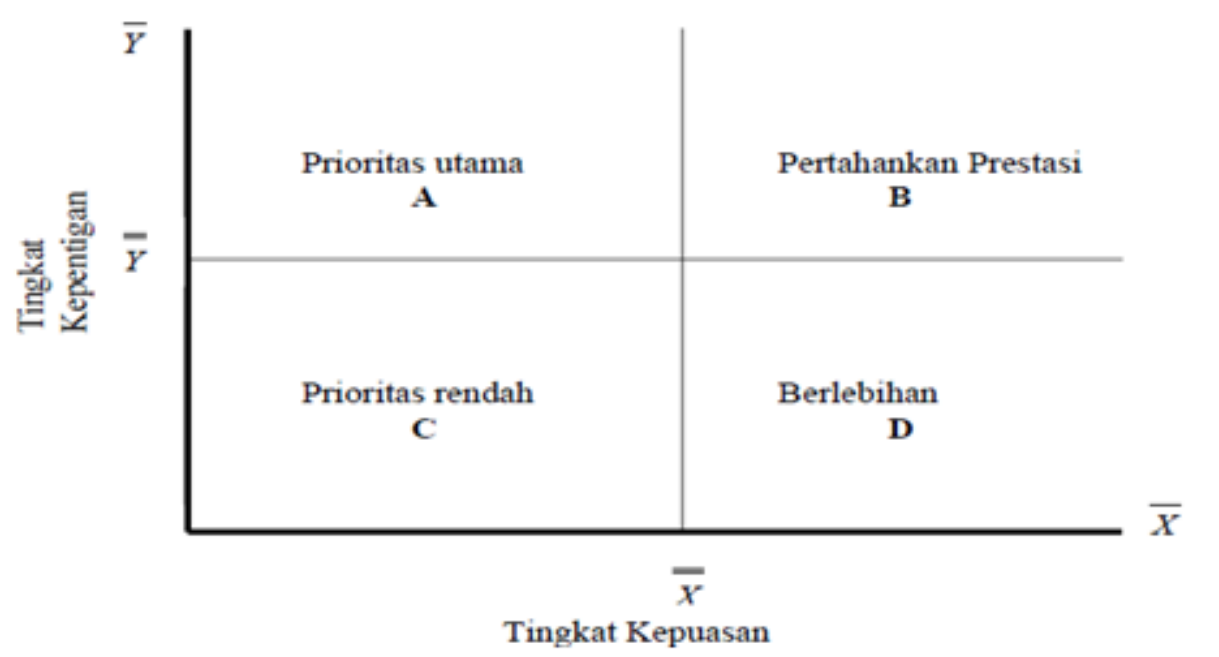

Keterangan:

A = Memperlihatkan atribut mutu yang dianggap penting dan dapat memengaruhi kepuasan konsumen, namun belum dipenuhi oleh produsen.

$\mathrm{B}=$ Memperlihatkan atribut mutu yang penting bagi konsumen dan telah berhasil dipenuhi oleh produsen.

$\mathrm{C}=$ Memperlihatkan atribut mutu yang pengaruhnya kurang penting pengaruhnya bagi konsumen, ditanggapi secara netral oleh produsen, dianggap kurang penting dan kurang memuaskan.

$\mathrm{D}=$ Memperlihatkan atribut mutu yang menurut konsumen kurang penting, akan tetapi sudah dipenuhi oleh produsen, dianggap kurang penting tapi sangat memuaskan.

Sumber: Rangkuti, 2002.

\section{Gambar 1 Diagram Kartesius}

\section{Teknik pengolahan data}

Teknik pengolahan data yang digunakan dalam penelitian ini adalah scoring. Scoring dilakukan saat kode jawaban atau hasil observasi telah ditetapkan sehingga nantinya setiap jawaban dari responden dapat diberikan nilai skor. Tidak ada pedoman khusus secara baku untuk scoring hanya saja harus konsisten dalam memberikan skor. Penghitungan skor kualitas dimulai dari menghitung skor item, selanjutnya menghitung skor variabel. Cara menghitung skor variabel adalah menentukan skor tingkat kinerja $(1,2,3,4)$ dikurangi skor tingkat kepentingan $(1,2,3,4)$. Setelah skor diperoleh selanjutnya dicari rentang skala (RS) dengan rumus (Simamora, 2020):

$$
\mathrm{RS}=\frac{\mathrm{m}-\mathrm{n}}{\mathrm{b}}
$$

Keterangan:

$\mathrm{RS}=$ rentang skala

$\mathrm{m}=$ Angka tertinggi dalam pengukuran

$\mathrm{n}=$ Angka terendah dalam pengukuran

$\mathrm{b}=$ Banyaknya kelas yang akan dibentuk

Berdasarkan rumus di atas, maka dilakukan penghitungan kualitas masing-masing dimensi (tangible, reliability, responsiveness, assurance dan emphaty) adalah sebagai berikut:

Nilai Minimal $=$ Jumlah Soal $\mathrm{x}$ Skor Terendah

$$
=5 \times(1-4)=5 \times(-3)=-15
$$

Nilai Maksimal $=$ Jumlah Soal $x$ Skor Tertinggi

$$
=5 \times(4-1)=5 \times 3=15
$$

Rentang skala $=$ Nilai Maksimal - Nilai Minimal

$$
\begin{aligned}
& =\frac{30}{5} \\
& =6
\end{aligned}
$$


Terdapat lima kategori, maka kriteria untuk kualitas adalah sebagai berikut:

1. Sangat berkualitas, skor 10 sampai dengan 15 .

2. Berkualitas, skor 4 sampai dengan 9.

3. Cukup berkualitas, skor 3 sampai dengan -3 .

4. Kurang berkualitas, skor -4 sampai dengan -9 .

5. Tidak berkualitas, skor -10 sampai dengan -15 .

\section{HASIL DAN PEMBAHASAN}

\section{Hasil Analisis Tingkat Kualitas Program Usaha Mikro Kecil Menengah (UMKM) LAZISMU Berdasarkan Dimensi}

\section{Dimensi tangible/bukti langsung}

1. Tingkat kualitas dimensi tangible. Sebagian besar mustahik (88.89\%) menilai tingkat kualitas layanan program UMKM LAZISMU Magetan pada dimensi tangible cukup berkualitas.

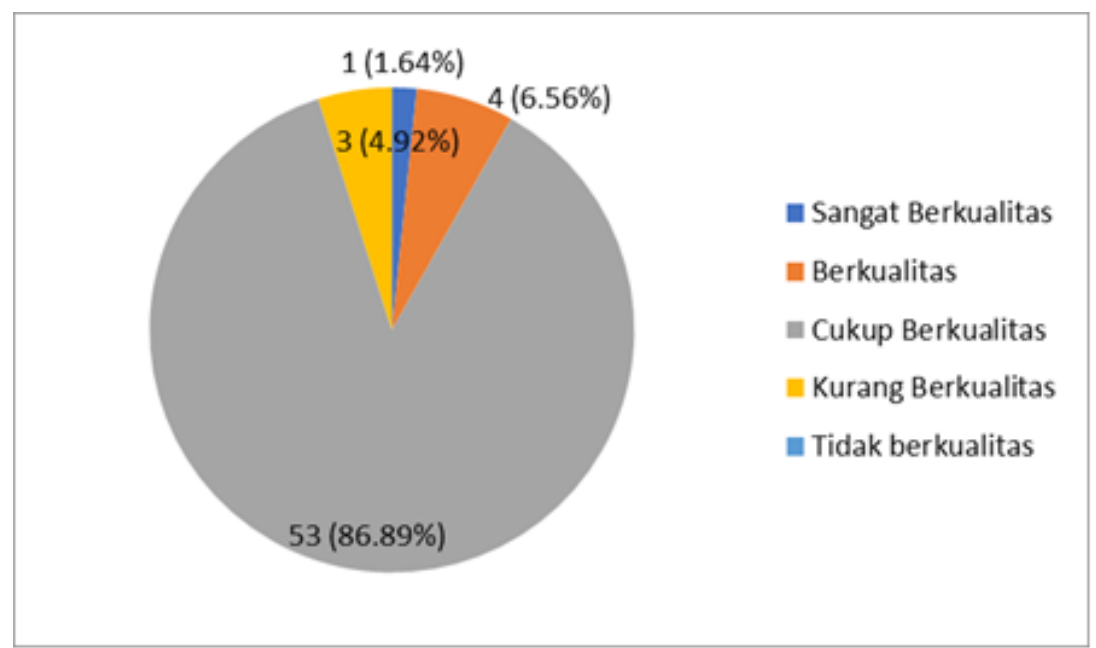

Sumber: Data primer, 2020.

Gambar 2 Diagram kualitas LAZISMU Magetan dimensi tangible

2. Distribusi masing-masing item dimensi tangible pada diagram kualitas sebagai berikut:

Tabel 1 Nilai total dan rata-rata item dimensi tangible

\begin{tabular}{|c|c|c|c|c|}
\hline \multirow{2}{*}{ Item } & \multirow{2}{*}{$\frac{\text { Kinerja }}{\mathrm{X}}$} & \multirow{2}{*}{$\frac{\text { Kepentingan }}{\mathrm{Y}}$} & \multicolumn{2}{|c|}{ Rata-rata } \\
\hline & & & $\mathbf{X}$ & $\mathbf{Y}$ \\
\hline $\begin{array}{l}\text { Letak strategis kantor } \\
\text { LAZISMU (mudah dijangkau). }\end{array}$ & 199 & 164 & 3.26 & 2.69 \\
\hline $\begin{array}{l}\text { Sarana informasi yang dimiliki } \\
\text { LAZISMU (surat, telepon dan } \\
\text { website). }\end{array}$ & 201 & 194 & 3.30 & 3.18 \\
\hline $\begin{array}{l}\text { Pedoman untuk survei } \\
\text { kelayakan mendapat bantuan. }\end{array}$ & 195 & 198 & 3.20 & 3.25 \\
\hline $\begin{array}{l}\text { Sarana penyaluran bantuan } \\
\text { (bantuan diantarkan ke rumah). }\end{array}$ & 198 & 195 & 3.25 & 3.20 \\
\hline $\begin{array}{l}\text { Bukti fisik bantuan (uang/ } \\
\text { barang). }\end{array}$ & 196 & 201 & 3.21 & 3.30 \\
\hline Rata-rata & & & 3.24 & 3.12 \\
\hline
\end{tabular}

Sumber: Data primer, 2020. 


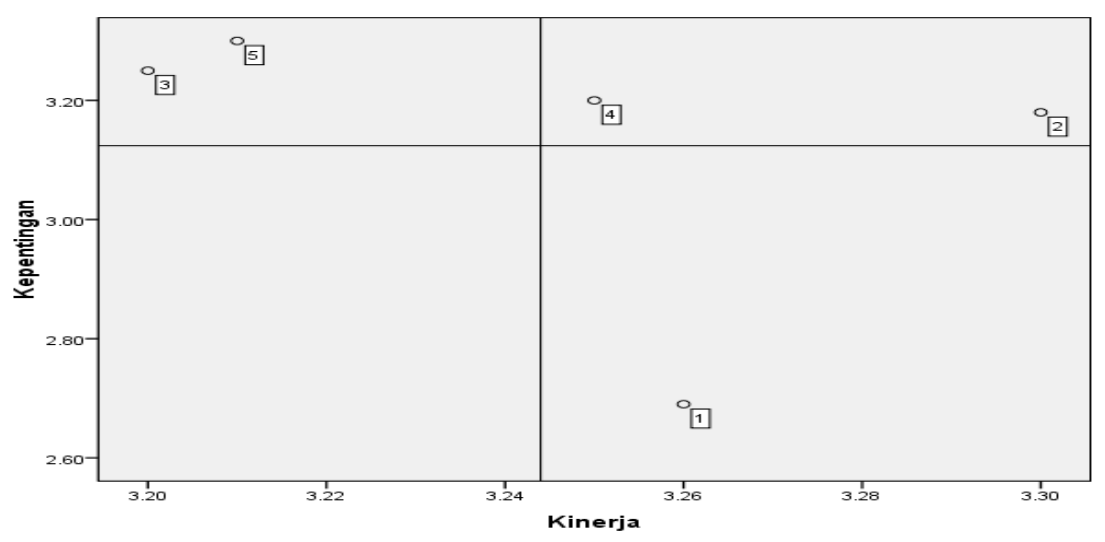

Sumber: Data primer, 2020.

Gambar 3 Diagram Kartesius tingkat kualitas dimensi tangible

Pada diagram di atas, item pedoman untuk survei kelayakan mendapat bantuan dan bukti fisik bantuan (uang/barang) berada pada kuadran A. Hal ini menunjukkan bahwa menurut mustahik kedua item tersebut dinilai sangat penting namun tingkat kinerja dinilai kurang baik. Item sarana informasi yang dimiliki LAZISMU (surat, telepon dan website) dan sarana penyaluran bantuan (bantuan diantarkan ke rumah) berada pada kuadran B. Hal ini menunjukkan bahwa menurut mustahik kedua item tersebut dinilai sangat penting dan tingkat kinerja dinilai sudah baik. Item letak strategis kantor LAZISMU (mudah dijangkau) berada pada kuadran D. Hal ini menunjukkan bahwa menurut mustahik item tersebut dinilai kurang penting, namun tingkat kinerja dinilai sudah baik, dalam arti letak kantor sudah strategis.

Dimensi tangible yaitu kemampuan perusahaan menunjukkan bukti kebendaannya secara fisik, seperti kebersihan ruangan, kondisi sarana prasarana, penampilan karyawan (Santoso, 2011). Pada dimensi ini hampir seluruh mustahik menilai bahwa sarana yang menunjang pelayanan program UMKM LAZISMU seperti letak strategis kantor LAZISMU (mudah dijangkau), sarana informasi yang dimiliki LAZISMU (surat, telepon, dan website), pedoman untuk survei kelayakan mendapat bantuan, sarana penyaluran bantuan (contoh: bantuan diantarkan ke rumah), dan bukti fisik bantuan (uang/ barang) sudah cukup berkualitas.

Peningkatan yang harus diprioritaskan adalah bukti fisik bantuan (uang/barang) dan pedoman untuk survei kelayakan mendapat bantuan. Menurut mustahik besaran bantuan diharapkan dapat ditingkatkan dan pedoman survei kelayakan untuk mendapatkan bantuan diharapakan dapat ditingkatkan. Adapun hasil wawancara dengan pengurus LAZISMU Magetan terkait besaran bantuan dari LAZISMU menunjukkan bahwa besaran bantuan sudah ditentukan berdasarkan dana yang ada dan berpedoman dari hasil survei. Sedangkan untuk pedoman survei sudah cukup jelas dan pengurus selalu menyampaikan hasil survei kepada mustahik.

Item yang harus dipertahankan adalah sarana penyaluran bantuan (contoh: bantuan diantarkan ke rumah) dan sarana informasi yang dimiliki LAZISMU (surat, telepon dan website) di mana menurut persepsi mustahik sudah sangat memuaskan. Hal yang menurut mustahik berlebihan adalah letak strategis kantor LAZISMU disimpulkan berlebihan karena mustahik menganggap kurang penting untuk letak namun sangat mudah dijangkau.

\section{Dimensi reliability/keandalan}

1. Tingkat kualitas dimensi reliability. Sebagian besar mustahik $(91.80 \%)$ menilai tingkat kualitas layanan program UMKM LAZISMU Magetan pada dimensi reliability cukup berkualitas. 


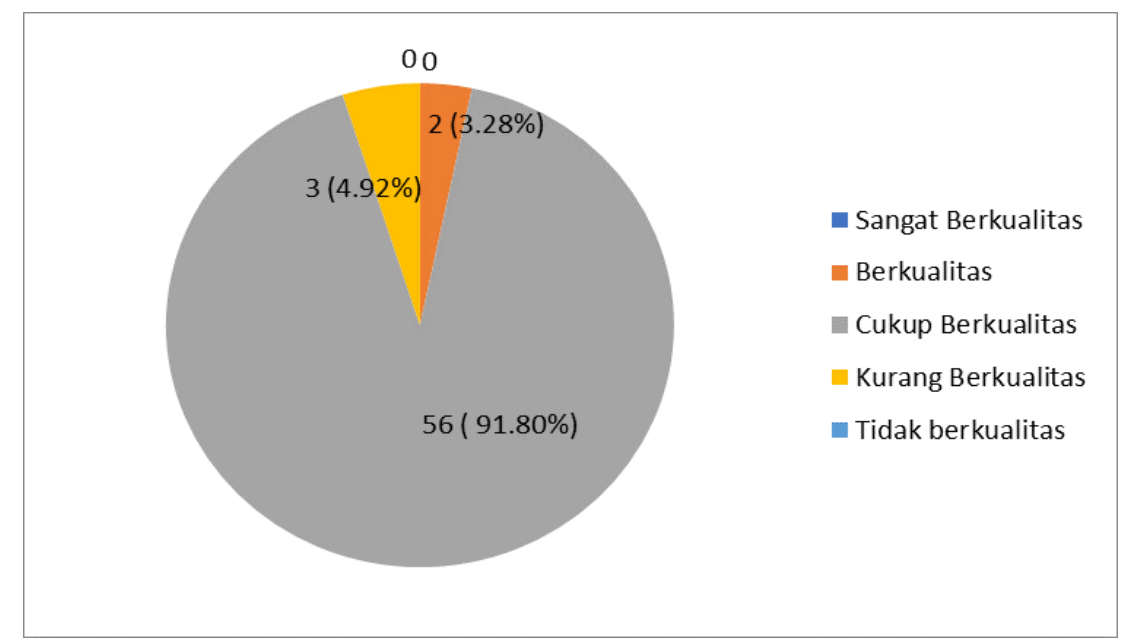

Sumber: Data primer, 2020.

Gambar 4 Diagram kualitas LAZISMU Magetan dimensi reliability

2. Distribusi masing-masing item dimensi reliability pada diagram kualitas sebagai berikut:

Tabel 2 Nilai total dan rata-rata item dimensi reliability

\begin{tabular}{|c|c|c|c|c|}
\hline \multirow{2}{*}{ Item } & \multirow{2}{*}{$\frac{\text { Kinerja }}{\mathrm{X}}$} & \multirow{2}{*}{$\frac{\text { Kepentingan }}{\mathrm{Y}}$} & \multicolumn{2}{|c|}{ Rata-rata } \\
\hline & & & $\mathbf{X}$ & Y \\
\hline $\begin{array}{l}\text { Kemudahan tata cara dalam } \\
\text { pengajuan bantuan. }\end{array}$ & 195 & 202 & 3.20 & 3.21 \\
\hline $\begin{array}{l}\text { Rentang waktu realisasi } \\
\text { dengan pengajuan bantuan. }\end{array}$ & 194 & 203 & 3.18 & 3.33 \\
\hline $\begin{array}{l}\text { Kesesuaian wujud barang/ } \\
\text { besaran biaya yang } \\
\text { direalisasikan. }\end{array}$ & 197 & 196 & 3.23 & 3.21 \\
\hline $\begin{array}{l}\text { Dampak positif } \\
\text { pemberdayaan terhadap } \\
\text { mustahik. }\end{array}$ & 198 & 196 & 3.25 & 3.21 \\
\hline $\begin{array}{l}\text { Kesesuaian antara segala hal } \\
\text { yang disampaikan/ dijelaskan } \\
\text { petugas dengan kenyataan. }\end{array}$ & 194 & 205 & 3.18 & 3.36 \\
\hline Rata-rata & & & 3.21 & 3.29 \\
\hline
\end{tabular}

Sumber: Data primer, 2020.

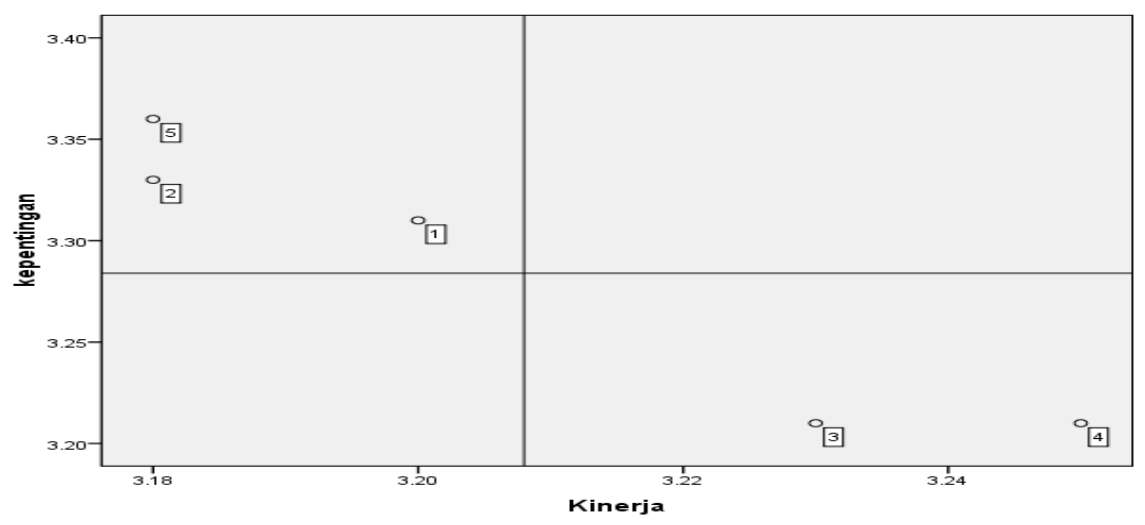

Sumber: Data primer, 2020.

Gambar 5 Diagram Kartesius tingkat kualitas dimensi reliability 
Berdasarkan diagram di atas, item kemudahan tata cara dalam pengajuan bantuan, rentang waktu realisasi dengan pengajuan bantuan dan item kesesuaian antara segala hal yang disampaikan/ dijelaskan petugas dengan kenyataan berada pada kuadran A. Hal ini menandakan bahwa tingkat kepentingan dinilai sangat penting dan tingkat kinerja dinilai kurang baik. Item kesesuaian wujud barang/besaran biaya yang direalisasikan dan dampak positif pemberdayaan terhadap mustahik menurut mustahik berada pada kuadran D. Hal ini menunjukkan bahwa tingkat kepentingan dinilai kurang penting namun tingkat kinerja dinilai sangat baik.

Dimensi reliability merupakan kemampuan memberikan pelayanan sesuai yang dijanjikan pada pelanggan (Santoso, 2011). Pada dimensi ini sebagian besar mustahik menilai bahwa kualitas layanan program UMKM LAZISMU sudah cukup berkualitas.

Hal yang memengaruhi kualitas dan menjadi prioritas utama adalah kesesuaian antara segala hal yang disampaikan/dijelaskan petugas dengan kenyataan, ketepatan waktu realisasi dengan pengajuan bantuan dan kemudahan tata cara dalam pengajuan bantuan. Kinerja LAZISMU dinilai masih rendah padahal kegiatan tersebut dinilai sangat penting. Menurut mustahik, diperlukan adanya penjelasan yang lebih detail, waktu realisasi lebih cepat dan cara pengajuan lebih mudah. Adapun hasil wawancara dengan pengurus LAZISMU terkait penjelasan yang diberikan pada mustahik menunjukkan bahwa sebenarnya pengurus sudah berusaha untuk memberikan penjelasan secara detail pada mustahik, tetapi kemungkinan terdapat kurang pemahaman dari sisi mustahik. Sedangkan untuk waktu realisasi memang tergantung analisis dari banyaknya mustahik yang mengajukan.

Item yang dinilai berlebihan adalah kesesuaian wujud barang/besaran biaya yang direalisasikan dan dampak positif pemberdayaan mustahik. Mustahik menilai kinerja LAZISMU dalam memberikan bantuan sudah sangat baik dan dapat meningkatkan ekonomi.

\section{Dimensi responsiveness/daya tanggap}

1. Tingkat kualitas dimensi responsiveness. Semua mustahik (100\%) menilai tingkat kualitas layanan program UMKM LAZISMU Magetan pada dimensi responsiveness cukup berkualitas.

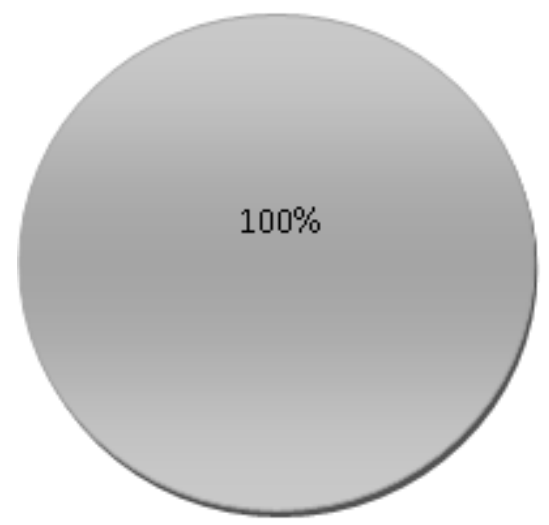

Sumber: Data primer, 2020.

Gambar 6 Diagram kualitas LAZISMU Magetan dimensi responsiveness 
2. Distribusi masing-masing item dimensi responsiveness pada diagram kualitas sebagai berikut:

Tabel 3 Nilai total dan rata-rata item dimensi responsiveness

\begin{tabular}{lcccc}
\hline \multicolumn{1}{c}{ Item } & Kinerja & Kepentingan & \multicolumn{2}{c}{ Rata-rata } \\
\cline { 2 - 5 } & $\mathbf{X}$ & $\mathbf{Y}$ & $\mathbf{X}$ & $\mathbf{Y}$ \\
\hline $\begin{array}{l}\text { Perhatian/respons terhadap } \\
\text { pengajuan (ditinjau dari } \\
\text { waktu). }\end{array}$ & 196 & 196 & 3.21 & 3.21 \\
$\begin{array}{l}\text { Keberadaan petugas dan } \\
\text { kesiapan dalam melayani di } \\
\text { jam kerja. }\end{array}$ & 197 & 200 & 3.23 & 3.28 \\
$\begin{array}{l}\text { Kemampuan petugas dalam } \\
\text { menjawab dan memberikan }\end{array}$ & 193 & 200 & 3.16 & 3.28 \\
$\begin{array}{l}\text { solusi terhadap masalah. } \\
\begin{array}{l}\text { Ketepatan sasaran untuk } \\
\text { mendapat bantuan. }\end{array}\end{array}$ & 203 & 200 & 3.33 & 3.28 \\
$\begin{array}{l}\text { Pemantauan terhadap dampak } \\
\text { pemberdayaan. }\end{array}$ & 198 & 193 & 3.25 & 3.16 \\
\hline Rata-rata & & & 3.24 & 3.24 \\
\hline
\end{tabular}

Sumber: Data primer, 2020.

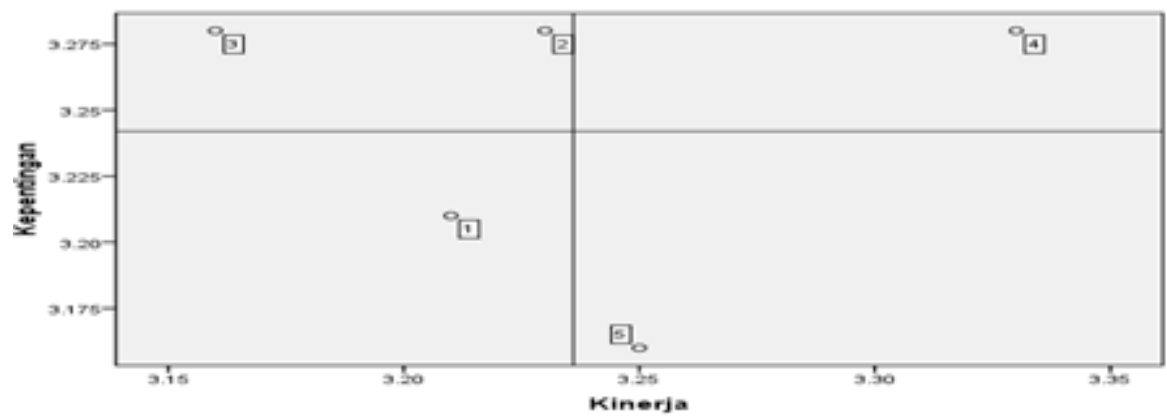

Sumber: Data primer, 2020.

Gambar 7 Diagram Kartesius tingkat kualitas dimensi responsiveness

Berdasarkan diagram di atas, item kemampuan petugas dalam menjawab dan memberikan solusi terhadap masalah, keberadaan petugas dan kesiapan dalam melayani di jam kerja berada pada kuadran A. Hal ini menandakan bahwa menurut mustahik tingkat kepentingan item-item tersebut dinilai sangat penting dan tingkat kinerja dinilai kurang baik. Item ketepatan sasaran untuk mendapat bantuan berada pada kuadran B. Hal ini menandakan bahwa tingkat kepentingan dinilai sangat penting dan tingkat kinerja dinilai sudah baik. Item perhatian/respons terhadap pengajuan (ditinjau dari waktu) berada pada kuadran C. Hal ini menandakan bahwa menurut mustahik item tersebut dinilai kurang penting dan tingkat kinerja dinilai kurang baik. Item pemantauan terhadap dampak pemberdayaan berada pada kuadran D. Hal ini menandakan bahwa menurut mustahik item tersebut dinilai kurang penting namun tingkat kinerja dinilai sudah baik.

Menurut Parasuraman, Zeithaml dan Berry dalam Santoso (2011), dimensi responsiveness adalah konsumen telah diberikan layanan dengan segera. Mustahik menilai dimensi ini cukup berkualitas. Item yang menjadi prioritas utama adalah kemampuan petugas dalam menjawab dan memberikan solusi terhadap masalah dan keberadaan petugas dalam melayani di jam kerja. Adapun hasil wawancara dengan pengurus LAZISMU terkait kemampuan petugas dalam menjawab dan memberikan solusi terhadap masalah, bahwa sebenarnya pengurus sudah berusaha memberikan jawaban dan solusi dengan baik, namun kemungkinan terdapat kurang pemahaman dari sisi mustahik. 
Hal yang perlu dipertahankan adalah ketepatan sasaran untuk mendapat bantuan. Pada item ini kinerja dinilai sudah baik. Hal yang termasuk prioritas rendah adalah perhatian/respons terhadap pengajuan (ditinjau dari waktu). Berdasarkan hasil wawancara dengan pengurus LAZISMU, kecepatan respons dipengaruhi oleh banyaknya mustahik yang mengajukan dengan kegiatan yang lain. Upaya yang harus ditingkatkan merespons layanan dengan cepat. Pemantauan terhadap dampak pemberdayaan sangat berlebihan dilihat dari pendapatan mustahik meningkat dari sebelumnya.

\section{Dimensi assurance/jaminan}

1. Tingkat kualitas dimensi assurance. Sebagian besar mustahik (88.52\%) menilai tingkat kualitas layanan program UMKM LAZISMU Magetan pada dimensi assurance cukup berkualitas.

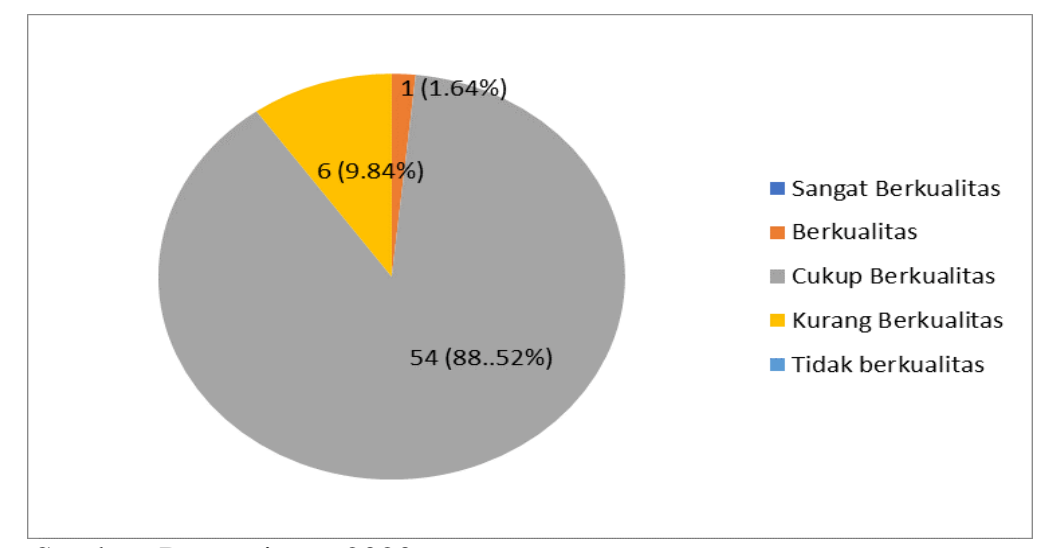

Sumber: Data primer, 2020.

Gambar 8 Diagram kualitas LAZISMU Magetan dimensi assurance

2. Distribusi masing-masing item dimensi assurance pada diagram kualitas sebagai berikut:

Tabel 4 Nilai total dan rata-rata item dimensi assurance

\begin{tabular}{lcccc}
\hline \multirow{1}{*}{ Item } & Kinerja & Kepentingan & \multicolumn{2}{c}{ Rata-rata } \\
\cline { 2 - 5 } & $\mathbf{X}$ & $\mathbf{Y}$ & $\mathbf{X}$ & $\mathbf{Y}$ \\
\hline $\begin{array}{l}\text { Transparansi dalam } \\
\text { memberikan informasi hasil }\end{array}$ & 164 & 193 & 2.69 & 3.16 \\
$\begin{array}{l}\text { survei. } \\
\begin{array}{l}\text { Adanya pendampingan dalam } \\
\text { pemberdayaan. }\end{array}\end{array}$ & 194 & 195 & 3.18 & 3.20 \\
$\begin{array}{l}\text { Jaminan terhadap } \\
\text { keberlangsungan } \\
\text { pemberdayaan. }\end{array}$ & 198 & 192 & 3.25 & 3.15 \\
$\begin{array}{l}\text { Teguran/sanksi terhadap } \\
\text { penyimpangan perjanjian. }\end{array}$ & 195 & 198 & 3.20 & 3.25 \\
$\begin{array}{l}\text { Kejelasan dalam penyampingan } \\
\text { semua informasi. }\end{array}$ & 201 & 203 & 3.30 & 3.33 \\
\hline Rata-rata & & & 3.12 & 3.22 \\
\hline
\end{tabular}

Sumber: Data primer, 2020. 


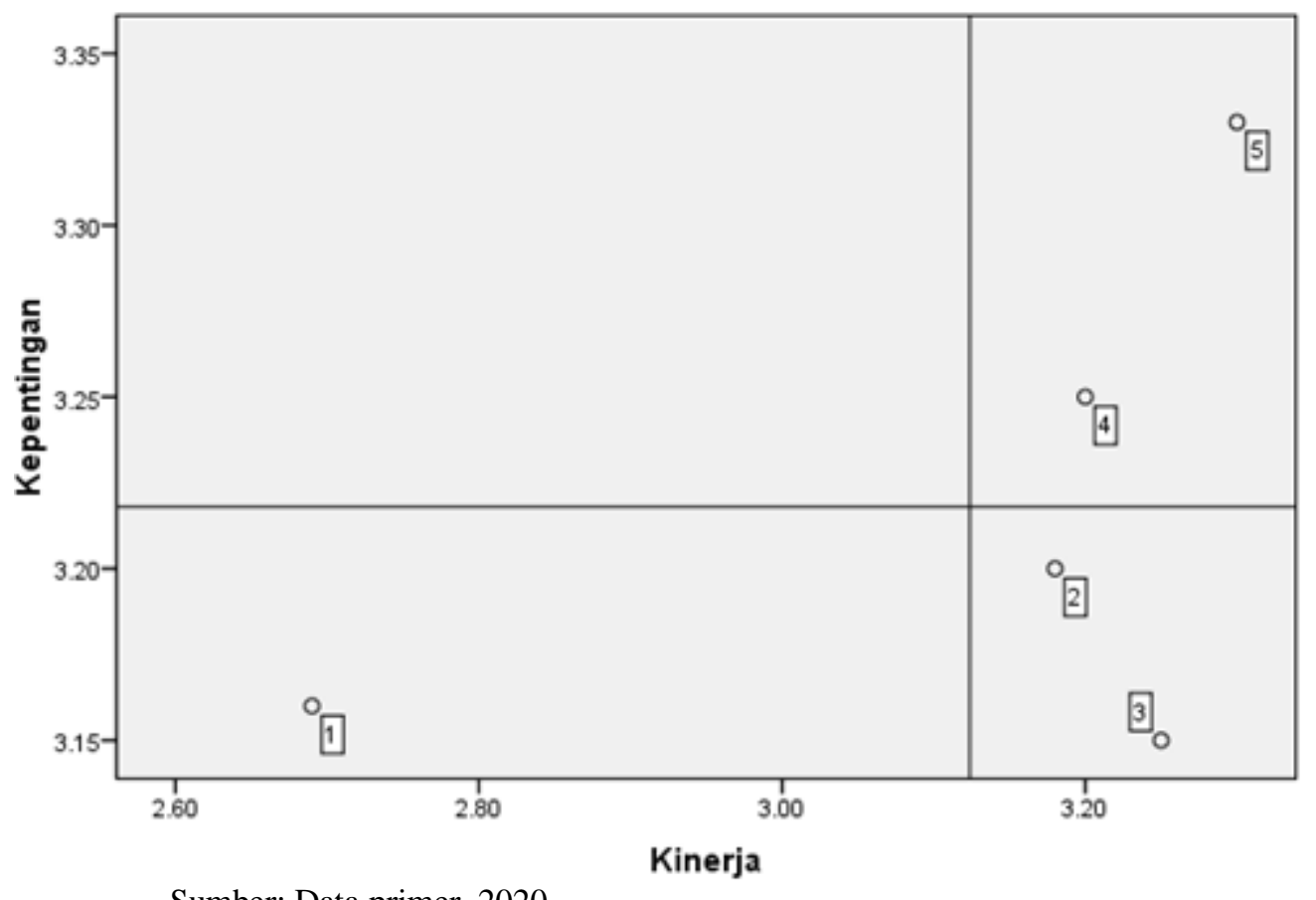

Sumber: Data primer, 2020.

Gambar 9 Diagram Kartesius dimensi assurance

Berdasarkan diagram di atas, item teguran/sanksi terhadap penyimpangan perjanjian dan kejelasan dalam penyampaian informasi berada pada kuadran B. Hal ini menandakan bahwa menurut mustahik tingkat kepentingan dinilai sangat penting dan tingkat kinerja dinilai kurang baik. Item transparansi dalam memberikan informasi hasil survei berada pada kuadran C. Hal ini menandakan bahwa menurut mustahik tingkat kepentingan dinilai kurang penting dan tingkat kinerja dinilai kurang baik. Item adanya pendampingan dalam pemberdayaan berada pada kuadran D. Hal ini menandakan bahwa menurut mustahik tingkat kepentingan dinilai kurang penting namun tingkat kinerja dinilai sudah baik.

Dimensi assurance mencakup pengetahuan, etika, serta sifat yang dapat dipercaya dari para karyawan dalam menumbuhkan kepercayaan kepada pelanggan (Santoso, 2011). Menurut persepsi mustahik, LAZISMU Magetan cukup berkualitas dalam menumbuhkan kepercayaan mustahik.

Hal yang harus dipertahankan adalah kejelasan dalam penyampaian semua informasi dan teguran/ sanksi terhadap penyimpangan perjanjian. Hal yang menjadi prioritas rendah adalah transparansi dalam memberikan informasi hasil survei. Menurut mustahik, item tersebut memiliki tingkat kepentingan kurang penting dan tingkat kinerja kurang baik. Hasil wawancara dengan pengurus LAZISMU menunjukkan bahwa penjelasan sudah diberikan terkait hasil survei. Yang menjadi berlebihan adalah adanya pendampingan memberikan informasi hasil dan jaminan terhadap keberlangsungan pemberdayaan. Proses pendampingan dan pemantauan sudah dilakukan oleh pengurus LAZISMU.

\section{Dimensi emphaty/perhatian}

1. Tingkat kualitas dimensi emphaty. Sebagian besar mustahik (93.44\%) menilai tingkat kualitas layanan program UMKM LAZISMU Magetan pada dimensi emphaty cukup berkualitas. 


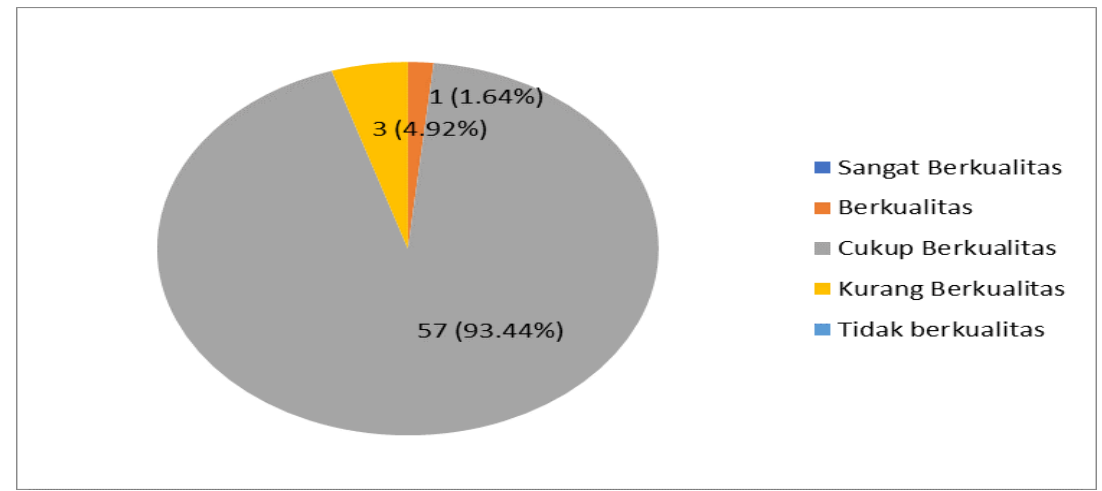

Sumber: Data primer, 2020.

Gambar 10 Diagram kualitas LAZISMU Magetan dimensi emphaty

2. Distribusi masing-masing item dimensi emphaty pada diagram kualitas sebagai berikut:

Tabel 5 Nilai total dan rata-rata item dimensi emphaty

\begin{tabular}{|c|c|c|c|c|}
\hline \multirow{2}{*}{ Item } & \multirow{2}{*}{$\frac{\text { Kinerja }}{\mathrm{X}}$} & \multirow{2}{*}{$\frac{\text { Kepentingan }}{\mathrm{Y}}$} & \multicolumn{2}{|c|}{ Rata-rata } \\
\hline & & & $\mathbf{X}$ & $\mathbf{Y}$ \\
\hline Kemampuan komunikasi petugas. & 204 & 207 & 3.34 & 3.39 \\
\hline Sopan santun, keramahan petugas. & 205 & 209 & 3.36 & 3.43 \\
\hline $\begin{array}{l}\text { Kemampuan petugas dalam perlakuan } \\
\text { yang sama terhadap mustahik. }\end{array}$ & 199 & 204 & 3.26 & 3.34 \\
\hline $\begin{array}{l}\text { Petugas memberikan kesempatan } \\
\text { kepada mustahik untuk memberikan } \\
\text { masukan, menyampaikan keinginan } \\
\text { dan keluhannya. }\end{array}$ & 196 & 211 & 3.21 & 3.46 \\
\hline $\begin{array}{l}\text { Respons terhadap hasil pemberdayaan } \\
\text { (contoh: berhasil memberikan pujian, } \\
\text { jika tidak berhaasil memberikan } \\
\text { kesempatan lagi). }\end{array}$ & 205 & 195 & 3.36 & 3.20 \\
\hline Rata-rata & & & 3.31 & 3.36 \\
\hline
\end{tabular}

Sumber: Data primer, 2020.

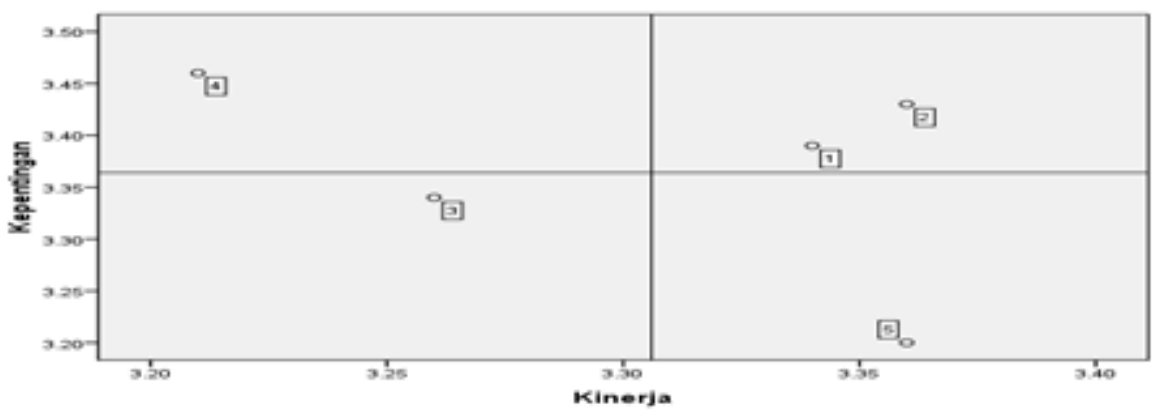

Sumber: Data primer, 2020.

Gambar 11 Diagram Kartesius dimensi emphaty

Berdasarkan diagram di atas, item petugas memberikan kesempatan kepada mustahik untuk memberikan masukan, menyampaikan keinginan dan keluhannya berada pada kuadran A. Hal ini menandakan bahwa menurut mustahik item tersebut dinilai sangat penting namun tingkat kinerja kurang baik. Item sopan santun, keramahan petugas dan kemampuan komunikasi petugas berada pada kuadran B. Hal ini menandakan bahwa menurut mustahik item tersebut dinilai sangat penting dan tingkat kinerja dinilai sudah baik. Item perlakuan yang sama terhadap mustahik berada pada kuadran 
C. Hak ini menandakan bahwa menurut mustahik tingkat kepentingan dinilai kurang penting dan tingkat kinerja dinilai kurang baik. Item respons terhadap hasil pemberdayaan (contoh: jika berhasil memberikan pujian, jika tidak berhasil memberikan kesempatan lagi) berada pada kuadran D. Hal ini menandakan bahwa menurut mustahik item tersebut dinilai kurang penting namun tingkat kinerja dinilai sudah baik.

Dimensi empathy adalah kepedulian terhadap karyawan dan individu. Empati meliputi kemudahan dalam berhubungan, pola komunikasi yang baik, perhatian pribadi, serta memahami kebutuhan pelanggan (Santoso, 2011). Pemberian perhatian secara individu kepada para mustahik untuk mengetahui keinginan dan kebutuhan yang terkait program UMKM. Menurut persepsi mustahik, dimensi ini sudah cukup berkualitas dalam memberikan perhatian yang bersifat individu.

Hal yang menjadi prioritas utama adalah petugas memberikan kesempatan kepada mustahik untuk memberikan masukan, menyampaikan keinginan dan keluhannya. Item yang harus dipertahankan adalah sopan santun, keramahan petugas dan kemampuan komunikasi petugas. Hal yang menjadi prioritas rendah dalam dimensi ini adalah perlakuan yang sama terhadap mustahik, tidak membedakan satu dengan yang lain, namun kinerja masih masih rendah. Hal yang berlebihan adalah respons terhadap hasil pemberdayaan (contoh: jika berhasil memberikan pujian, jia tidak berhasil memberikan kesempatan lagi).

\section{Hasil Analisis Tingkat Kualitas Program Usaha Mikro Kecil Menengah (UMKM) LAZISMU Seluruh Dimensi}

Kualitas layanan program UMKM LAZISMU Magetan pada seluruh dimensi dapat dilihat pada tabel dan diagram berikut:

Tabel 6 Nilai total dan rata-rata seluruh dimensi

\begin{tabular}{lcccc}
\hline \multirow{2}{*}{ Item } & Kinerja & Kepentingan & \multicolumn{2}{c}{ Rata-rata } \\
\cline { 2 - 5 } & $\mathbf{X}$ & $\mathbf{Y}$ & $\mathbf{X}$ & $\mathbf{Y}$ \\
\hline Tangible & 989 & 952 & 16.21 & 15.61 \\
Reliability & 978 & 1002 & 16.03 & 16.43 \\
Responsiveness & 982 & 989 & 16.10 & 16.21 \\
Assurance & 952 & 981 & 15.61 & 16.08 \\
Emphaty & 1009 & 1026 & 16.54 & 16.82 \\
\hline Rata-rata & & & 16.10 & 16.23 \\
\hline
\end{tabular}

Sumber: Data primer, 2020.

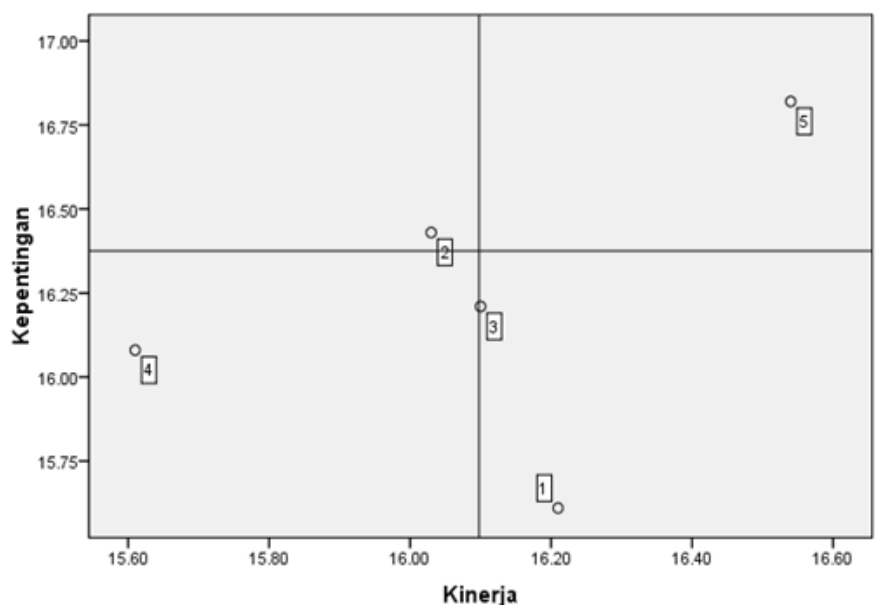

Sumber: Data primer, 2020.

Gambar 12 Diagram Kartesius seluruh dimensi 
Diagram di atas menunjukkan bahwa dimensi reliable (keandalan) merupakan atribut mutu yang ratarata mustahik menganggap penting namun LAZISMU Magetan belum memberikan layanan yang memuaskan. Dimensi empathy (empati) dianggap penting dan sudah memuaskan. Dimensi assurance (jaminan) dianggap kurang penting dan belum memuaskan. Dimensi responsiveness (daya tanggap) dianggap kurang penting namun rata-rata mustahik menyatakan memuaskan. Dimensi tangible (bukti fisik) dianggap kurang penting namun sudah memuaskan.

Dimensi reliable (keandalan) berada tepat antara prioritas utama dan prioritas rendah. Hal ini menurut mustahik dianggap penting namun tingkat kinerja kurang baik. Dimensi assurance (jaminan) menjadi prioritas rendah, menurut mustahik penting dan kinerja kurang baik. Dimensi emphaty (empati) harus dipertahankan karena menurut mustahik penting dan kinerja sudah sangat baik. Dimensi responsiveness (daya tanggap) berada pada pertengahan antara prioritas rendah dan berlebihan. Menurut mustahik kurang penting namun kinerja cukup baik. Dimensi tangible (bukti fisik) termasuk kategori berlebihan. Menurut mustahik kurang penting namun kinerja sangat baik.

\section{SIMPULAN}

Penelitian ini menyimpulkan bahwa kualitas LAZISMU Magetan dalam program pemberdayaan Usaha Mikro Kecil dan Menengah (UMKM) menurut persepsi mustahik pada masing-masing dimensi tangible, reliable, responsiveness, assurance, dan emphaty hampir seluruhnya cukup berkualitas. Kualitas LAZISMU Magetan dalam program pemberdayaan Usaha Mikro Kecil dan Menengah (UMKM) ditunjukkan oleh item kemudahan tata cara dalam pengajuan bantuan, rentang waktu realisasi dengan pengajuan bantuan. Penelitian ini juga memberikan hasil temuan bahwa item kesesuaian antara segala hal yang disampaikan/dijelaskan petugas dengan kenyataan pada dimensi reliable merupakan faktor prioritas utama sedangkan item sopan santun, keramahan petugas dan kemampuan komunikasi petugas pada dimensi emphaty merupakan faktor yang harus dipertahankan.

Temuan akhir penelitian ini adalah item transparansi dalam memberikan informasi hasil survei dimensi assurance merupakan faktor prioritas rendah sedangkan item pemantauan terhadap dampak pemberdayaan pada dimensi responsiveness dan item letak strategis kantor LAZISMU (mudah dijangkau) pada dimensi tangible dinilai berlebihan. Penelitian ini menyarankan LAZISMU untuk mempercepat dalam realisasi pengajuan bantuan dan mempermudah dalam proses pengajuan bantuan.

\section{DAFTAR PUSTAKA}

Ariani, D. \& Anwar, M. K. (2018). Program pemberdayaan zakat bagi UMKM pada rumah zakat Kota Surabaya. Jurnal Ekonomika dan Bisnis Islam, 1(1), 13-24.

Beik, I. S., \& Arsyianti, L. D. (2015). Construction of CIBEST model as measurement of poverty and welfare indices from Islamic perspective. Al-Iqtishad: Jurnal Ilmu Ekonomi Syariah, 7(1), 87104.

Fandy T. (2006). Manajemen Jasa. Yogyakarta (ID), Andi.

Hakim, R., Muslikhati, M. \& Rifa'i, M. N. (2020). Zakat dan pemberdayaan ekonomi mustahik: Studi pada Lembaga Amil Zakat, Infak dan Shodaqoh Muhammadiyah (LAZISMU) Kabupaten Malang. Jurnal Ilmiah Ekonomi Islam, 6(3), 469-477.

Izdihar, R. A., \& Widiastuti, T. (2019). Peran Lembaga Amil Zakat Muhammadiyah (LAZISMU) Surabaya dalam pemberdayaan UMKM perempuan di Surabaya melalui pemanfaatan dana infaq dan shadaqah. Jurnal Ekonomi Syariah Teori Dan Terapan, 6(3), 525-540.

Kholidah, N., \& Salma, A. N. (2019). Filantropi kreatif: Pemberdayaan ekonomi umat berbasis zakat produktif pada program 1000 UMKM LAZISMU Kabupaten Pekalongan. Cakrawala: Jurnal Studi Islam, 14(2), 93-101.

Kosasih, P. C. (2014). Analisa Kualitas Pelayanan Menggunakan Metode Servqual dan Diagram 
Kartesius pada Layanan Pembayaran PLN Di PT Pelangi Indodata(Disertasi, President University, Bekasi, Indonesia).

Kotler. (1997). Dasar-Dasar Pemasaran Principles Of Marketing. Jakarta (ID), PT Prenhallindo.

[LAZISMU JATENG] Lembaga Amil Zakat Infaq Shadaqah Muhammadiyah Jawa Tengah. (2020). 5 Pilar Program [Internet]. [diakses 2020 Des 19]. Tersedia pada: http://www.lazismujatim.org/?Page_id=4372.

Lubis, A. S., \& Andayani, N. R. (2017). Pengaruh kualitas pelayanan (service quality) terhadap kepuasan pelanggan PT. Sucofindo Batam. Journal of Applied Business Administration, 1(2), 232-243.

Rizal, E., Khadijah, U. L. S., \& Anwar, R. K. (2020). Pemasaran Produk Usaha Mikro, Kecil dan Menengah (UMKM) dalam Kegiatan Wisata di Desa Cipacing Kabupaten Sumedang. Tornare: Journal of Sustainable and Research, 2(2), 36.

Rohmah, N. (2017). Pemberdayaan Usaha Mikro Kecil dan Menengah (UMKM) pada Lembaga Inkubator Bisnis BAZNAS (Tesis, UIN Syarif Hidayatullah, Jakarta, Indonesia).

Sanrego, Y. D., \& Taufik, M. (2016). Fiqih Tamkin: Membangun Modal Sosial dalam Mewujudkan Khairu Ummah. Jakarta (ID), Qisthi Press.

Santoso, Heru. (2011a). Kualitas Layanan Kesehatan Menurut Persepsi Konsumen. Magetan (ID), Forikes.

Santoso, Heru. (2011b). Kualitas Layanan Kesehatan Menurut Persepsi Konsumen. Magetan (ID), Frokeis.

Sarwat, A. (2019). Ensiklopedia Fikih Indonesia. Jakarta (ID), PT Gramedia.

Setiawan, A., Qomariah, N., \& Hermawan, H. (2019). Pengaruh Kualitas Pelayanan terhadap Kepuasan Konsumen. Jurnal Sains Manajemen dan Bisnis Indonesia, 9(2), 114-126.

Simamora, B. (2020). Panduan Riset Perilaku Konsumen. Jakarta (ID), PT Gramedia Pustaka Utama. Sugiyono. (2012). Memahami Penelitian Kualitattif. Bandung (ID), Alfabeta.

Wijayanti, R. (2015). Analisis Implementasi Pemberdayaan Usaha Mikro (Studi Pada Lembaga Zakat Infaq dan Shadaqah Muhammadiyah (LAZISMU) Kabupaten Malang) (Disertasi, Universitas Brawijaya, Malang, Indonesia). 